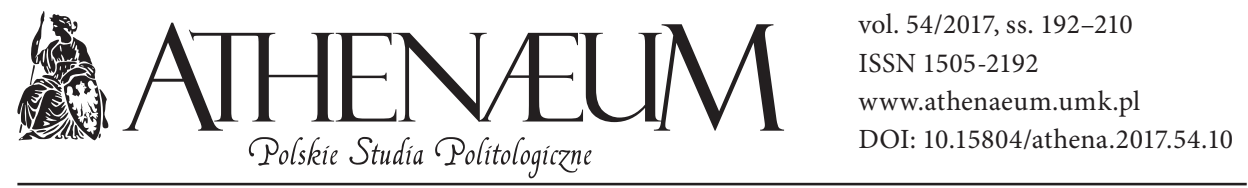

\title{
SŁOWEŃCY W KARYNTII: WYBRANE ZAGADNIENIA
}

\author{
SLOVAKS IN CARINTHIA: SELECTED ISSUES
}

\author{
Ewa Godlewska*
}

\begin{abstract}
ABSTRAKT
Artykuł stanowi próbę wskazania i zbadania czynników, które zdaniem autorki miały zasadniczy wpływ na współczesną sytuację mniejszości słoweńskiej w Karyntii. Wśród nich znalazły się m.in. spory terytorialne o Karyntię, sytuacja geopolityczna Austrii po II wojnie światowej oraz dwustronne relacje ze Słowenią. Szczególny nacisk położony został na ostatni z wymienionych czynników. Podstawowym pytaniem badawczym pozostaje kwestia, czy takie relacje można zaliczyć do podstawowych czynników sprawczych. Artykuł stanowi również próbę weryfikacji tezy, według której geografia i historia państwa należą do głównych czynników określających jego politykę. Analiza dotyczy w głównej mierze Karyntii - jednego z dziewięciu austriackich landów, który bezpośrednio graniczy ze Słowenią (obok Styrii). Jest to terytorium, w którym mniejszość słoweńska pozostaje najbardziej aktywna. Nie bez znaczenia jest również liczebność mniejszości oraz fakt, że Karyntia uchodzi za tradycyjny obszar jej zamieszkiwania.
\end{abstract}

\begin{abstract}
This article is an attempt to identify and examine factors that, according to the author, had a fundamental influence on the contemporary situation of the Slovenian minority in Carinthia. These include, among others, territorial disputes with Carinthia, the geopolitical situation of Austria after World War II, and the bilateral relations with Slovenia. Particular emphasis has been placed on the last of these factors. Bilateral relations have a huge impact on ethnic policies of individual countries. They are one of the external factors that shape the situation of national minorities. This article is an attempt to analyze the importance of good neighborly relations for ethnic relations in Austria. The basic research question is the issue of whether such relationships can be classified as primary causal factors. The article is also an attempt to verify the argument that the geography and history of the state are the main factors that determine its policies. The analysis concerns mainly Carinthia - one of nine Austrian federal states, which directly borders with Slovenia (next to Styria). This is the territory in which the Slovene minority remains the most active. Not without significance is the number of minori-
\end{abstract}

* Uniwersytet Marii Curie-Skłodowskiej, Wydział Politologii. 
Słowa kluczowe: Austria, Słowenia, Karyntia, mniejszości narodowe, grupy narodowościowe ties and the fact that Carinthia is regarded as a traditional area of habitation.

Keywords: Austria, Slovenia, Carinthia, national minority, ethnic group

\section{UWAGI WSTĘPNE}

Słoweńcy w Karyntii stanowią jedną z sześciu uznanych mniejszości w Austrii. Są jedną z najliczniejszych i najbardziej aktywnych społeczności w państwie. Dysponują szerokim zakresem praw kulturowych, językowych i oświatowych ${ }^{1}$. Ich relacje ze społeczeństwem większościowym przez wiele stuleci nie należały jednak do przyjaznych. Wydaje się, że współcześnie udało się osiągnąć pewnego rodzaju status quo. Droga do kompromisu nie była jednak łatwa i obfitowała w liczne dramatyczne momenty.

Celem niniejszego artykułu nie jest jednak analiza statusu prawnego Słoweńców w Karyntii. Ramy artykułu nie pozwalają na dokonanie tego w sposób szczegółowy i rzetelny. Artykuł stanowi próbę wskazania i zbadania czynników, które miały zdaniem autorki zasadniczy wpływ na współczesną sytuację tej społeczności. Wśród nich znalazły się m.in. spory terytorialne o Karyntię, sytuacja geopolityczna Austrii po II wojnie światowej czy chociażby dwustronne relacje ze Słowenią. Należy mieć na uwadze, że sytuacja ta wynika również z szeregu innych czynników. Nacisk położony został jednak na trzy wymienione powyżej, ze szczególnym uwzględnieniem stosunków dobrosąsiedzkich. Wywierają one bowiem ogromny wpływ na politykę etniczną poszczególnych państw. Są jednym z czynników zewnętrznych, które kształtują sytuację mniejszości narodowych. Przyczyną takiego stanu rzeczy jest oczywiście rozmieszczenie grup mniejszościowych. Są to społeczności zamieszkujące bardzo często tereny przygraniczne. W wyniku różnego rodzaju konfliktów, decyzji politycznych, sojuszy czy też

1 Prawa te regulowane są przede wszystkim następującymi aktami prawnymi: art. 7 i 8 Federalnej Ustawy Zasadniczej Austrii (Bundes-Verfassungsgesetz, BGBl. I Nr 68/2000), Traktatem Państwowym z 1955 roku (Wiederherstellung eines unabhängigen und demokratischen Österreich, BGBl. Nr. 152/1955), Ustawą o grupach narodowościowych z 1976 roku (Bundesgesetz vom 7. 7. 1976 über die Rechtsstellung von Volksgruppen in Österreich, BGBl. Nr. 396/1976) oraz wydanymi na jej podstawie rozporządzeniami , Ustawą o nauczaniu mniejszościowym w Karyntii z 1959 roku (Minderheiten-Schulgesetz für Kärnten, BGBl. Nr. 101/1959), ale również Ustawą o stowarzyszeniach z 2002 roku (Bundesgesetz über Vereine 2002, BGBl. I Nr 66/2002), Ustawą o radiofonii i telewizji z 2004 roku (Bundesgesetz über den Österreichischen Rundfunk und Fernsehen/ORF-Gesetz, BGBl. I Nr. 97/2004) itp. 
innych czynników utraciły bezpośrednią więź z macierzą. Bliskość terytorialna sprawia jednak, że wspomniane relacje pozostają bliskie. $Z$ jednej strony mamy więc do czynienia $\mathrm{z}$ wparciem państwa ościennego, z drugiej - taka sytuacja może przyczyniać się do wielu kryzysów, m.in. ze względu na dużą pokusę ingerencji w stosunki wewnętrzne.

W związku z próbą analizy znaczenia relacji dobrosąsiedzkich dla stosunków etnicznych w Austrii podstawowym pytaniem badawczym pozostaje kwestia, czy takie relacje można zaliczyć do podstawowych czynników sprawczych - nie tylko w wymiarze regionalnym, ale i całego państwa. Artykuł stanowi również próbę weryfikacji tezy, według której geografia i historia państwa należą do głównych czynników określających jego politykę.

Analiza dotyczy jednego z dziewięciu austriackich landów, w którym mniejszość słoweńska pozostaje najbardziej aktywna. Nie bez znaczenia jest również liczebność mniejszości oraz fakt, że Karyntia uchodzi za tradycyjny obszar jej zamieszkiwania. Mniejszość słoweńska obecna jest także w Styrii. Stanowi jednak niewielki odsetek wszystkich mieszkańców landu (Volkszählung 2001. Hauptergebnisse I - Steiermark, 2003, s. 19)². Nadmienić należy, że mniej liczne skupiska mniejszości słoweńskiej odnotowano również w Wiedniu, w Voralbergu, Dolnej i Górnej Austrii. W pozostałych landach mieliśmy do czynienia z niewielką, raczej symboliczną reprezentacją. Zgodnie z przyjętą polityką to jednak na terytorium dwóch pierwszych wymienionych powyżej landów mniejszość uznana została przez austriackie władze za grupę narodowościową ${ }^{3}$.

W artykule skoncentrowano się na wydarzeniach XX oraz XXI wieku. W treści znalazły się jednak odniesienia do lat wcześniejszych. Informacje te stanowią jednak wyłącznie tło historyczne. Mają charakter przekrojowy i są pewnego rodzaju wprowadzeniem do rozważań nad czynnikami kształtującymi sytuację mniejszości słoweńskiej w Karyntii.

2 Podczas spisu powszechnego w 2001 roku zaledwie 2192 osób w Styrii wskazało język słoweński jako używany w życiu codziennym, co stanowiło 0,19\% wszystkich mieszkańców landu. Gminy najliczniej zamieszkane przez członków mniejszości słoweńskiej znajdowały się na południu Styrii. Największy odsetek odnotowano w 2001 roku w okręgu Radkersburg. W innych częściach landu większe skupiska znajdowały się w mieście Graz oraz okręgach Graz-Umgebung i Leibnitz.

3 Takie nazewnictwo obowiązuje w Austrii od 1976 roku. Wprowadzono je na mocy Ustawy o grupach narodowościowych. Zgodnie z $\$ 1$ ust. 2 ustawy stanowią je grupy, których członkowie wskazują takie cechy, jak obywatelstwo austriackie, własny język różniący się od języka niemieckiego oraz własne cechy etniczne. Bardzo istotnym pozostaje ponadto kryterium zamieszkania na terytorium państwa od co najmniej trzech pokoleń. Obecnie według władz wymogi te spełniają Słoweńcy, Chorwaci, Węgrzy, Czesi, Słowacy i Romowie. 


\section{POCZATTKI OSADNICTWA I KSZTAŁTOWANIE SIĘ ŚWIADOMOŚCI NARODOWEJ KARYNCKICH SŁOWEŃCÓW}

Karyntia to land, który najliczniej zamieszkiwany jest przez mniejszość słoweńską. U progu XXI wieku liczebność grupy szacuje się na kilkanaście tysięcy. Dokładnych informacji dostarczają nam wyniki spisu powszechnego z 2001 roku $^{4}$. Według danych liczbowych w landzie żyło 12554 obywateli należących do grupy słoweńskiej. Wymieniona liczba stanowiła 2,4\% wszystkich mieszkańców Karyntii (Volkszählung 2001. Hauptergebnisse I - Kärnten, 2003, s. 17). Członkowie mniejszości zamieszkiwali głównie południowe gminy, położone najbliżej granicy austriacko-słoweńskiej. Od lat tradycyjnymi okręgami słoweńskimi pozostają Völkermarkt/Velikovec, Villach/Beljak, czy Klagenfurt/Celovec.

Przodkami karynckich Słoweńców byli Słowianie Alpejscy (Alpenslawen), obecni na obszarze dzisiejszej Austrii od VI wieku. Pierwotnym obszarem ich osiedlania była wschodnia część Alp. Około 700 roku n.e. zaczęto ich określać jako Karantanie (Karyntianie, Chorutanie, łac. Carantani) ${ }^{5}$. W VII wieku założyli jedno z pierwszych państw słowiańskich - Karantanię (Koroška). Obejmowała ona tereny dzisiejszej Karyntii, duży obszar Styrii oraz Dolnej Austrii. Księstwo zachowało niezależność do połowy następnego stulecia, kiedy to zdecydowano o poddaniu się zwierzchnictwu i opiece Franków. Całkowite podporządkowanie nastąpiło jednak dopiero w IX wieku. Wskutek poparcia nieudanego powstania władcy chorwackiego Ljudevita Posawskiego Karantania została zlikwidowana a jej terytorium włączone do Księstwa Bawarskiego. Słowiańscy książęta zostali zastąpieni przez panów feudalnych i hrabiów frankijskich (I am, 2001, s. 10; Kärntner Slowenen, 1993, s. 9).

Mniej więcej w XV wieku zaczęła być widoczna granica językowa na tym obszarze. Ludność słoweńskojęzyczna przeciwstawiana była niemieckojęzycznej. Wielu pisarzy i badaczy słoweńskich skłaniało się do tego, aby ten okres opisywać jako czas niewoli i ujarzmienia. Słoweńcom przypisywali natomiast rolę męczenników, gnębionych przez władców frankijskich (Slawisches Österreich,

${ }^{4}$ Późniejsze badania nie uwzględniają już pytań o pochodzenie etniczne czy tzw. Umgangsprache. W 2011 roku tradycyjny spis został bowiem zastąpiony specjalnym rejestrem urzędowym (Registerzählung). Obecnie dane nie są zbierane na podstawie kwestionariuszy wypełnianych przez obywateli, lecz pochodzą z akt spraw administracyjnych. Pochodzenie etniczne lub też język ojczysty nie są w nich na ogół ujmowane.

${ }^{5}$ Często posługiwano się także innymi określeniami. W źródłach łacińskich Słoweńcy to Sclavani lub Sclavi. Germanowie nazywali ich Winadi, Winades, względnie Winedi lub Winden. 
2006). Sytuację pogarszał fakt, że terytorium dzisiejszej Karyntii było w kolejnych stuleciach obszarem wielokrotnych najazdów tureckich. Pewne zmiany w sytuacji słoweńskojęzycznej ludności przyniosła natomiast reformacja. Od tego okresu zauważyć można było rozwój życia kulturowego Słoweńców. Publikowane były pierwsze książki w języku słoweńskim o tematyce religijnej, ale również słowniki i różnego rodzaju podręczniki. France Prešeren, sławny słoweński poeta, przyczynił się natomiast do tego, że jego ojczysty język zagościł w europejskich salonach. Można go także nazwać prekursorem ruchu narodowego Słoweńców. W swoich poemacie „Zdravljica” (Toast) z 1844 roku zawarł hasło walki zbrojnej o niepodległość Słowenii (Slawisches Österreich, 2006). Późniejsze reformy Marii Teresy i Józefa II, choć wymierzone przeciwko wszelkim tendencjom odśrodkowym, paradoksalnie doprowadziły również do ożywienia etnicznego. Były czynnikiem sprawczym konsolidacji narodu przeciwko wspólnemu zagrożeniu.

Wraz z początkiem XIX wieku wzrosło znaczenie języka słoweńskiego, który w okresie tzw. Prowincji Iliryjskich (Les Provinces Illyriennes ${ }^{6}$ ) wprowadzony został do administracji oraz szkolnictwa na poziomie elementarnym (Wereszycki, 1986, s. 50). Kluczową dla świadomości narodowej Słoweńców była Wiosna Ludów. Pojawiły się wówczas pierwsze programy narodowe (m.in. autorstwa Matiji Majara Ziljskiego, zawierający postulat zjednoczenia wszystkich Słoweńców oraz równouprawnienia ich języka z językiem niemieckim), co świadczyło o wzroście aktywności w sferze politycznej (Kärntner Slowenen, 1993, s. 11; Chlebowczyk, 1983, s, 238).

Począwszy od roku 1867, przewagę zdobywały jednak wpływy niemieckie i węgierskie, co odbywało się kosztem ludności słoweńskojęzycznej. Język grupy wypierany był z życia publicznego, systemu szkolnictwa, w mniejszym stopniu z życia kulturowego. Sytuację pogarszał fakt, że na koniec XIX wieku przypadł kryzys gospodarczy, obejmujący właśnie terytorium zamieszkiwane przez Słoweńców. Można było zaobserwować powolny upadek regionów górniczych oraz przemysłu hutniczego (Baumgartner, 1955, s. 31). Dodatkowym ciosem był wybuch I wojny światowej. Mniejszość słoweńska wyszła z niej osłabiona - zarówno pod względem liczebnym, jak i organizacyjnym. To jednak pierwsze powojenne lata zadecydowany o sytuacji Słoweńców Karynckich. W wyniku walk o przebieg granic oraz w konsekwencji referendum z 1920 roku los tej

6 Prowincje ustanowiono w 1809 roku, a obejmowały one terytoria Dalmacji, Gorycji, Istrii, Triestu, krainy, część Karyntii i Chorwacji. 
społeczności został przypieczętowany. Większość terytorium landu pozostało w granicach Austrii.

Dopiero w drugiej połowie XX wieku możliwa była odbudowa życia organizacyjnego Słoweńców w Karyntii. Proces ten w ogólnym rozrachunku przebiegał pomyślnie i współcześnie mniejszość ta pozostaje najbardziej aktywną grupą ze wszystkich uznanych austriackich mniejszości. Bogate życie organizacyjne i kulturowe, aktywny udział w życiu publicznym oraz własna partia polityczna ${ }^{7}$ to elementy świadczące o wewnętrznej sile społeczności. Z drugiej jednak strony aktywność na różnych płaszczyznach i walka o realizację praw mniejszości stanowiła i ciągle stanowi przyczynę lokalnych konfliktów. Niejednokrotnie przybierały one dramatyczny obrót. Stały się również przyczyną napięć na linii Wiedeń-Lublana.

\section{KARYNTIA JAKO PRZEDMIOT SPORÓW TERYTORIALNYCH W XX WIEKU}

W ubiegłym stuleciu Karyntia stała się areną dramatycznych wydarzeń. W konsekwencji I wojny światowej oraz rozpadu Austro-Węgier rozpoczęła się walka o przyszłość landu. W pierwszych miesiącach po zakończeniu działań wojennych doszło do radykalizacji nastrojów wśród słoweńskojęzycznej ludności Karyntii. Na stosunek do państwa austriackiego wpływ miały wydarzenia rozgrywające się tuż za granicą landu. 1 grudnia 1918 roku utworzono Królestwo Serbów, Chorwatów i Słoweńców. Królestwo powstało na bazie Państwa Serbów, Chorwatów i Słoweńców, proklamowanego 29 października tego samego roku. Miało to być ucieleśnieniem jednego z czołowych haseł - utworzenia wspólnej państwowości dla południowych Słowian. W jej skład miała wejść także duża część Karyntii. Austriaków zaczęto więc postrzegać jako wrogów i istotną przeszkodę na drodze ku zjednoczeniu.

W wyniku roszczeń Lublany doszło do tzw. karynckiej wojny obronnej (Kärntner Abwehrkampf). Wydarzenia te zostały później upamiętnione w hymnie

\footnotetext{
7 Reprezentacją polityczną Słoweńców w Karyntii jest Enotna Lista (Lista Jedności). Jest to jedyna tego typu samodzielna formacja na austriackiej scenie politycznej. Powstała w 1991 roku. Jednym z głównych punktów programowych partii jest wzmocnienie dwujęzyczności Karyntii, poprzez równouprawnienie języka słoweńskiego we wszystkich dziedzinach życia publicznego. Istotnymi celami EL są także gospodarcze i kulturowe wzmocnienie regionu oraz poprawienie stosunków dobrosąsiedzkich.
} 
Karyntii. W ostatniej jego zwrotce znajduje się sformułowanie „wo man mit Blut die Grenze schrieb” („gdzie granicę krwią zapisano”). Walki o przebieg granicy trwały do 1919 roku i zakończyły się okupacją Klagenfurtu/Celovca przez siły serbskie. Ostatecznie jednak o losach landu zadecydowało referendum, które zgodnie z postanowieniami konferencji pokojowej w Paryżu zostało przeprowadzone w dniu 10 października 1920 roku (Valentin, 2005, s. 19-28).

W głosowaniu 59,01\% uprawnionych opowiedziało się za przynależnością Karyntii do Austrii. Z wszystkich głosów „za”, których w sumie było 22 025, aż 12 tys. pochodziło od zamieszkujących land Słoweńców. Największe poparcie dla pozostania w granicach państwa austriackiego odnotowano w gminie Pustritz (96,79\% głosów). W części południowej landu proporcje były jednak odmienne. Słynną stała się gmina Zell Pfarre/Sele Cerkev. Tam aż 96,78\% głosujących opowiedziało się za połączeniem z Królestwem SHS (Kärntner Slowenen, 1993, s. 12).

W wyniku referendum przypieczętowany został los Słoweńców z Karyntii. W pierwszych latach od plebiscytu konsekwencje podjętej w 1920 roku decyzji były bardzo bolesne. Przyczyna tkwiła w prowadzonej wówczas polityce. Wraz ze wzrostem nastrojów nacjonalistycznych zaczęto odchodzić od realizacji wcześniejszych zobowiązań, przyjętych m.in. na mocy Traktatu z Saint Germain (Staatsvertrag, 1920) ${ }^{8}$. Nazwy w języku słoweńskich były usuwane z życia publicznego, a jedynym nauczanym w szkołach językiem był niemiecki. Język mniejszości eliminowany był także z życia religijnego. W wyniku działań austriackich władz wielu członków społeczności zdecydowało się na opuszczenie landu. Wśród emigrantów znakomitą część stanowili księża oraz nauczyciele (Kärntner Slowenen, 1993, s. 14).

Na mocy postanowień plebiscytu Karyntia w ogromnej części pozostała w granicach Austrii. Królestwo SHS, a następnie od 1929 roku Królestwo Jugosławii, nie pogodziło się jednak z jego wynikiem. Zachętą do roszczeń terytorialnych była trudna sytuacja państwa austriackiego. Po zakończeniu I wojny światowej powstał bowiem twór o słabej kondycji ekonomicznej, nękany dodatkowo kryzysami gospodarczymi z lat dwudziestych i trzydziestych. Społeczeństwo austriackie również było osłabione. Duża jego cześć nie wierzyła w możliwość przetrwania oraz uważała się za odłam narodu niemieckiego. W okresie międzywojennym - przede wszystkim w ostatnich latach poprzedzających wybuch

${ }^{8}$ W art.68 ust.2 Traktatu przewidziano wsparcie dla mniejszości w działalności oświatowej, religijnej i dobroczynnej. 
kolejnego globalnego konfliktu - pozostawała pod dużym wpływem nazistowskich Niemiec.

Roszczenia terytorialne do Karyntii odżyły po II wojnie światowej. Uzasadnieniem miał być fakt niewywiązywania się rządu w Wiedniu z warunków ustalonych w 1920 roku. Zdaniem władz Socjalistycznej Federacyjnej Republiki Jugosławii zamiast równych praw mieliśmy do czynienia z asymilacją i germanizacją. Świadczyć o tym miały statystyki, potwierdzające negatywny wpływ polityki dwudziestolecia międzywojennego na populację ludności słoweńskojęzycznej w Karyntii. O ile w 1910 roku jej liczebność szacowano na 66 tys. mieszkańców, to w 1923 liczba ta miała wynosić 37 tys., a w 1934 zaledwie 26 tys.(Vouk, 2015) .

Dokonanie stosownych zmian terytorialnym było jednym z ówczesnych postulatów, których realizacja miała przyczynić się do ochrony ludności na tym terenie. Roszczenia nie zostały jednak spełnione, co wynikało z kilku istotnych przesłanek. Po pierwsze władze jugosłowiańskie utraciły poparcie Moskwy. Pierwsze lata po II wojnie światowej stały pod znakiem ostrego konfliktu między Stalinem a Broz Tito. Aby zrozumieć znaczenie tego faktu, należy odnieść się do sytuacji Austrii w omawianym okresie. Austrię (podobnie jak państwo niemieckie) podzielono na cztery strefy okupacyjne: amerykańską, brytyjską, francuską i sowiecką. Taki sam podział dotyczył samego Wiednia. W obliczu takiego stanu oraz nie do końca jednoznacznej odpowiedzi dotyczącej roli Austrii w II wojnie światowej rodziło się pytanie o przyszłość struktur państwowych. Dysponując poparciem jednego z okupantów, Jugosławia mogłaby ugrać więcej, a przynajmniej dysponować ważną kartą przetargową. Tak się jednak nie stało. Drugą przyczyną, z powodu której nie doszło do zmian terytorialnych w obrębie Karyntii, była sama postawa władz austriackich. Trudna sytuacja polityczna, podział na strefy okupacyjne, ewentualne ryzyko podziału to tylko niektóre czynniki powodujące obawy przed zaostrzeniem konfliktu na innych płaszczyznach. W zamian za odstąpienie od roszczeń terytorialnych, rekompensatę dla jugosłowiańskiego rządu miały stanowić nowe gwarancje prawne dla mniejszości w Karyntii.

9 Co ciekawe, zgodnie ze spisem przeprowadzonym przez nazistów w 1939 roku odnotowano w Karyntii obecność 42 tys. Słoweńców. Spis odbywał się jednak w specyficznych warunkach, pod przymusem i z wyłączeniem elementu dobrowolności. Miał służyć niemieckiej propagandzie oraz być elementem polityki zagłady. 
Pierwszym krokiem była próba uregulowania systemu nauczania. 3 października 1945 roku Rząd Tymczasowy wydał Rozporządzenie o dwujęzycznym nauczaniu w Karyntii. Na jego mocy wprowadzono system obowiązkowej nauki języka słoweńskiego. W praktyce we wszystkich placówkach objętych rozporządzeniem (107 szkół ludowych) uczniowie mieli być nauczani w języku niemieckim oraz języku mniejszości (Fischer, 1980, s. 203). W ośmiu z nich nigdy nie zrealizowano istniejącego prawa. $W$ dwunastu następnych zaniechano nauki w języku mniejszości w ciągu najbliższych lat, a nieco ponad dekadę później zmieniono prawo w tym zakresie na bardziej zachowawcze. Prawdziwym przełomem miał być jednak rok 1955, kiedy uchwalono Traktat Państwowy.

Kwestie sporne dotyczące przyszłości Karyntii wpłynęły w znaczący sposób na życie organizacyjne mniejszości słoweńskiej. Podczas II wojny światowej oraz w latach następnych doszło do rozłamu ideologicznego wewnątrz grupy. Część członków wyraźnie opowiedziała się za przyłączeniem do Jugosławii, tworząc w 1945 roku Front Wyzwolenia Słoweńców Karynckich (Befreiungsfront für Slowenisch-Kärntner, Osvobodilna fronta za slovensko Koroško). Ugrupowanie reprezentowało poglądy lewicowe i wpierało komunistyczne rządy na Bałkanach (Kärntner Slowenen, 1993, s. 51). Na bazie jego struktur powstał później (w 1955 roku) Centralny Związek Organizacji Słoweńskich w Karyntii (Zentralverband slowenischer Organisationen in Kärnten, Zveza slovenskih organizacij na Koroškem). Bardziej zachowawcze postawy znalazły odzwierciedlenie w utworzeniu w 1949 roku Rady Słoweńców Karynckich (Rat der Kärtner Slowenen, Narodni svet koroških Slovencev).

Obecnie obie struktury odgrywają ważną rolę w życiu mniejszości. Ciągle widoczny jest jednak podział. Związek prezentuje interesy środowisk liberalnych i lewicowych, podczas gdy Rada - chrześcijańskich.

\section{WOKÓ TRAKTATU PAŃSTWOWEGO}

Traktat Państwowy z 1955 roku dotyczył odbudowy niezależnego i demokratycznego państwa austriackiego. Było to jednoznaczne z zakończeniem okresu okupacji. Wprowadzenie Traktatu w życie oznaczało ogromne zmiany, także dla zamieszkujących Austrię mniejszości. Z ich punktu widzenia niezmiernie istotny miał się okazać artykuł 7, określany niekiedy jako „Wielka Karta Praw Mniejszości”(Vouk, 2015). Artykuł ten obowiązuje do dnia dzisiejszego i co najważniejsze - posiada rangę konstytucyjną. 
W punkcie pierwszym stwierdzono, iż „Obywatele austriaccy należący do mniejszości słoweńskiej i chorwackiej, zamieszkujący mieszane pod względem etnicznym terytorium Karyntii, Burgenlandu oraz Styrii, korzystają z tych samych praw co pozostali obywatele Austrii, włącznie z prawem do zakładania i posiadania własnych organizacji, zgromadzeń, jak również prasy we własnym języku" (Wiederherstellung, 1955) ${ }^{10}$. W pozostałych punktach przewidziano natomiast prawa edukacyjne, językowe oraz kulturowe. W szczególności dotyczyły one prawa do nauki w językach wspomnianych mniejszości na poziomie elementarnym, do zakładania własnych placówek oświatowych, prawa do używania słoweńskiego i chorwackiego jako języków pomocniczych (w przewidzianych prawem okręgach administracyjnych i sądowych), prawa do dwujęzycznych oznaczeń o charakterze topograficznym oraz prawa do zachowania tożsamości kulturowej. W artykule 7 zawarto również zakaz działalności wszelkich organizacji, których celem byłoby odebranie powyższych praw mniejszościom.

Oczekiwania mniejszości narodowych wobec postanowień Traktatu Państwowego były ogromne. Początkowa euforia szybko jednak przygasła. Realizacja postanowień artykułu 7 okazała się bardzo trudna i legła u podstaw trudnych relacji austriacko-jugosłowiańskich w drugiej połowie ubiegłego wieku. Taki stan rzeczy wynikał w dużej mierze z charakteru samego Traktatu. Stanowił on bowiem zobowiązanie narzucone przez inne państwa, co może tłumaczyć późniejszą niechęć władz do ich wypełniania.

Praktycznie od pierwszych lat obowiązywania Traktatu władze jugosłowiańskie zgłaszały zastrzeżenia. Na porządku dziennym były noty dyplomatyczne, w których zwracano uwagę na rzeczywistą sytuację Słoweńców w Karyntii. Sytuacje konfliktowe narastały w latach sześćdziesiątych i siedemdziesiątych ubiegłego wieku. Kwestie te były przedmiotem rozmów podczas oficjalnej wizyty delegacji jugosłowiańskiej w Wiedniu w 1972 roku. Udało się jednak dojść do porozumienia i oba rządy wyraziły chęć zapewnienia szerszych praw mniejszościom (Popławski, 1995, s. 98-99). Pierwszym krokiem miała być Ustawa o dwujęzycznych nazwach o charakterze topograficznym w Karyntii z 1972 roku (Bundesgesetz, 1972).

Nowe porozumienie okazało się nietrwałe. Ustawa o dwujęzycznych nazwach szybko została zawieszona w wyniku ostrych protestów ze strony austriackich

${ }^{10}$ W Traktacie można było również odnaleźć odwołania do kwestii mniejszości w samej preambule, w której stwierdzono, że Austria zobowiązuje się do uznania podstawowych praw człowieka oraz praw politycznych mniejszości narodowych mieszkających na jej terytorium. 
nacjonalistów, popieranych przez dużą część niemieckojęzycznych mieszkańców Karyntii. Wydarzenia z tego okresu określane są jako „wojna tablicowa” (Ortstafelkrieg). Podczas protestów dochodziło do niszczenia dwujęzycznych tablic, szykanowania lokalnych polityków popierających prawa mniejszości itp. W obliczu zaistniałej sytuacji rząd w Jugosławii ponownie oskarżył Austrię o nieprzestrzeganie praw mniejszości narodowych, a nawet ich dyskryminowanie. Zaostrzające się stosunki w Karyntii były jednym z impulsów do uregulowania kwestii narodowościowych w nowej formie - w formie Ustawy o grupach narodowościowych z 7 lipca 1976 roku (Bundesgesetz, 1976). Ustawa obowiązuje do dnia dzisiejszego, jest jedną z najstarszych tego typu regulacji w Europie i stanowi w dużej mierze konkretyzację artykułu 7 Traktatu Państwowego.

Podczas prac przygotowawczych nad nową ustawą uwidoczniła się pewna charakterystyczna tendencja. Centralne władze w Wiedniu początkowo skłonne były na większe ustępstwa niż władze związkowe w Karyntii. Te pierwsze miały na uwadze stosunki z południowym sąsiadem. Jednak to władze niższego szczebla odgrywały wówczas kluczową rolę. H.G. Heinrich pisał, że „dla wszystkich wtajemniczonych jest publiczną tajemnicą, że rząd krajowy Karyntii posiada rodzaj weta we wszystkich ważniejszych sprawach stosunków austriacko-jugosłowiańskich" (Popławski, 1955, s. 101). Wiedeńscy decydenci musieli się więc liczyć z głosami swoich lokalnych kolegów, a przyczyną takiego stanu rzeczy była „obawa rządzących w Wiedniu partyjnych polityków przed utratą głosów"(Popławski, 1955, s. 101). Z tego też względu ówczesna sytuacja mniejszości słoweńskiej oraz niechęć do realizacji praw jej członków to wypadkowa mniej lub bardziej subtelnej gry politycznej. Głównymi rozgrywającymi miały być centralne i związkowe ośrodki władzy, główne partie polityczne (w tym istniejąca już na scenie politycznej skrajna Austriacka Partia Wolnościową - Freiheitliche Partei Österreichs/FPÖ) oraz przyglądający się sytuacji rząd jugosłowiański.

\section{STOSUNKI DOBROSĄSIEDZKIE A WSPÓŁCZESNY STATUS MNIEJSZOŚCI SŁOWEŃSKIEJ W KARYNTII}

Mimo wejścia w życie nowej ustawy regulującej status grup narodowościowych w Austrii, sytuacji w Karyntii daleko było do stabilizacji. Ostatnie dekady ubiegłego wieku upłynęły pod znakiem napięć na tle etnicznym. Konflikt dotyczył przede wszystkim praw językowych mniejszości. 
Na konflikt nałożył się wzrost popularności partii Jörga Haidera (FPÖ) słynącej z radykalnych poglądów i sentymentu do nazizmu. Już na początku lat osiemdziesiątych, pod przewodnictwem kontrowersyjnego polityka rozpoczęła się akcja przeciwko dwujęzycznemu nauczaniu. Polityk przedstawił wówczas postulat, aby nauczanie w języku słoweńskim było możliwe wyłącznie w kilku specjalnie oznakowanych placówkach. Reprezentanci mniejszości dopatrywali się w tym znamion dyskryminacji, czy wręcz „gettoizacji”. Planów tych nie udało się zrealizować, między innymi z powodu zdecydowanego sprzeciwu środowiska akademickiego (Vouk, 2015).

Kontrowersje wokół dwujęzycznego nauczania w gminach Karyntii powróciły pod koniec XX wieku. Tym razem kwestią sporną okazało się obsadzanie stanowisk dyrektorskich w dwujęzycznych szkołach Karyntii. Wielu specjalistów z zakresu oświaty, jak i same organizacje reprezentujące mniejszość słoweńską postulowały, aby dyrektorzy posiadali odpowiednie umiejętności językowe. Haider z kolei nie podzielał takiego pomysłu, uważając, że wymóg ten powinien być brany pod uwagę wyłącznie w tych placówkach, w których co najmniej połowa uczniów została zgłoszona do nauczania dwujęzycznego ${ }^{11}$. Co więcej, ostentacyjnie rozpisywał konkursy na wspomniane stanowiska, w których całkowicie pomijano znajomość języka słoweńskiego. Taka sytuacja zaistniała w roku szkolnym 2000/2001 między innymi w szkołach ludowych w miejscowościach Gödersdorf, Latschach, Maria Rain oraz Ferlach (2. Bericht, 2007, s. 141-142).

Władze w Lublanie z uwagą przyglądały się działaniom Haidera, jednak przyczyną największego napięcia w relacjach austriacko-słoweńskich stała się kwestia dwujęzycznych oznaczeń o charakterze topograficznym. Na początku XXI wieku to właśnie ta sprawa zdominowała stosunki etniczne w Karyntii. Niezadowolenie w wielu kręgach wywołała liberalizacja prawa z 2001 roku. W wyniku orzeczenia Federalnego Trybunału Konstytucyjnego dotychczasowy wymóg 25\%, odnoszący się do minimalnego udziału mniejszości w ogólnej liczbie mieszkańców danej gminy i będący warunkiem niezbędnym do korzy-

11 Na mocy Ustawy o nauczaniu mniejszościowym w Karyntii z 1959 roku (BGBl. Nr. 101/1959) obowiązuje tzw. zasada zgłoszenia. Wymóg ten oznacza, że naukę w języku słoweńskim może podjąć jedynie to dziecko, którego rodzice lub prawni opiekunowie zgłoszą w jego imieniu chęć przystąpienia do takiej nauki. Warto jednak zauważyć, że prawo to przysługuje także dzieciom niebędącym członkami mniejszości. Przynależność do grupy słoweńskiej nie jest tutaj żadnym ograniczeniem. Zgłoszenie musi być jednak złożone w momencie przyjęcia do szkoły. Rodzice mogą to także uczynić na początku każdego roku szkolnego. Takie zgłoszenie pozostaje ważne przez wszystkie lata nauki w danej placówce. Wyjątkiem jest jedynie rezygnacja z takiego nauczania. Ta może być jednak złożona jedynie pod koniec każdej klasy. 
stania z prawa do dwujęzycznych oznaczeń o charakterze topograficznym, został zastąpiony klauzulą 10\%. Przeciwnikiem takiej zmiany był między innymi sam Haider. Po pierwsze krytykował fakt zaangażowania Trybunału w kwestię ochrony mniejszości w Austrii. Sędziom zarzucał przekroczenie ich własnych kompetencji. Po drugie ostro sprzeciwił się ówczesnemu przewodniczącemu Trybunału - Ludwigowi Adamovichowi. Oskarżył go o stronniczość i domagał się jego odwołania. Zarzucił mu, że w trakcie badania sprawy spotkał się z prezydentem Słowenii - Milanem Kučanem, pomijając natomiast całkowicie reprezentację Karyntii (Kamer, 2006, s. 89-91).

Sprawie towarzyszyło wiele emocji i wzajemnych oskarżeń. Skutkiem samego orzeczenia było wznowienie publicznych dyskusji dotyczących sytuacji w dwujęzycznej Karyntii. Także w samej Słowenii wzrosło zainteresowanie sytuacją w austriackim landzie. Tamtejsze media rozpisywały się o „austriackiej Grecji” (gdzie prawo nie przewiduje dwujęzycznych oznaczeń). Konflikt podsycany był zapowiedziami Haidera dotyczącymi kierunkowskazów na drogach tranzytowych landu, które miały wskazywać wkrótce kierunek do „Laibach”, a nie do „Ljubljany”. Miał to być pewnego rodzaju odwet za to, że w Słowenii brak było tablic w języku niemieckim. Haider nawoływał również do oparcia polityki państwowej na czystości etnicznej. W 2006 roku nie miał nic przeciwko akcji rozsyłania SMS-ów o antysłoweńskich treściach ("Mörderische" SMS, 2006).

Po tragicznej śmierci polityka w 2008 roku atmosfera w Karyntii uległa zmianie. Nastąpiła pewna normalizacja, choć sytuacja Słoweńców w Karyntii wciąż wzbudza zainteresowanie władz w Lublanie.

Mimo wspomnianych wyżej problemów, dwustronne relacje nabrały pod koniec ubiegłego stulecia nowego znaczenia. Po upadku żelaznej kurtyny, powstaniu Słowenii, a w późniejszym okresie wspólnym członkostwie w Unii Europejskiej stosunki między państwami zyskały nową jakość. Z racji bezpośredniej bliskości stały się jednym z priorytetów. Ścisła współpraca w sferze ochrony środowiska, gospodarki, kultury czy administracji to tylko niektóre przykłady. W Lublanie mieści się obecnie jedno z jedenastu Biur Miasta Wiednia. Poprzez ich sieć organizowane są wspólne projekty szkoleniowe, imprezy kulturalne, festiwale itp. Ściślejsza współpraca otworzyła również nowe możliwości dla karynckich Słoweńców. Wiele z działających na terytorium landu stowarzyszeń utrzymuje bliskie kontakty ze swoimi odpowiednikami w Słowenii. Podobnie sytuacja przedstawia się w przypadku szkół. Przykładem może być słoweńska szkoła muzyczna w miejscowości Bleiburg/Pliberk (Kärtner Musikschule, Glasbena šola na Koroškem). Dzieci często uczestniczą w wymianie uczniów, wyjeż- 
dżają na koncerty do Słowenii itp. Ściśle współpracują również ze sobą austriackie i słoweńskie uniwersytety. Warto wspomnieć o Uniwersytecie w Klagenfurcie, który ma podpisane umowy z placówkami w Lublanie oraz Mariborze. Na ich podstawie każdego roku organizowane są między innymi wymiany studentów. Podobną współpracę podjęły uniwersytety z innych austriackich landów - z Graz (Styria), Innsbrucku (Tyrol) oraz Wiednia.

Na uwagę zasługuje również współpraca międzynarodowa ukierunkowana na wzmacnianie standardów ochrony praw mniejszości narodowych. Oprócz wspólnego członkostwa w Radzie Europy czy OBWE warto powiedzieć o przedsięwzięciach regionalnych. Jednym z przykładów jest Inicjatywa Środkowo-Europejska. Pod taką nazwą państwa z tej części kontynentu współpracują od połowy 1992 roku. Jej początków należy dopatrywać się natomiast w roku 1989, kiedy to nastąpiło zbliżenie Austrii, Jugosławii, Węgier i Włoch. Co ciekawe - była to pierwsza tego typu inicjatywa w tej części Europy. Współpracę podjęły: państwo neutralne, niebędące członkiem żadnego ówczesnego sojuszu, państwo z Układu Warszawskiego oraz z NATO. Zmiany geopolityczne w Europie, które wkrótce nastąpiły, nie przekreśliły dotychczasowej współpracy. Były wręcz dodatkowym bodźcem do jej zacieśnienia.

W kręgu zainteresowań państw Inicjatywy Środkowo-Europejskiej pozostaje między innymi kwestia ochrony praw człowieka oraz mniejszości narodowych. Podczas spotkań szefów rządów państw członkowskich często podkreślany jest fakt, że poszanowanie praw osób należących do mniejszości narodowych stanowi ważny czynnik utrzymania stabilności w regionie. Jednym $z$ dokumentów dotyczących tej problematyki jest natomiast Instrument ochrony praw mniejszości IŚE.

Ciekawym przykładem współpracy jest Wspólnota Robocza Alpen - Adria (Arbeitsgemeinschaft Alpen-Adria/Delovna skupnost Alpe-Jadran), przekształcona w 2015 roku w Sojusz Alpejsko-Adriatycki. Jest to obecnie jedna z czołowych organizacji działających w regionie. Została utworzona 20 listopada 1978 roku. Zrzesza jedenaście podmiotów z pięciu państw europejskich. Należą do nich austriackie landy Burgenland, Karyntia, Górna Austria oraz Styria, włoskie regiony Lombardia, Wenecja oraz Fruli - Wenecja Julijska, węgierskie komitaty Baranya i Vas, jak również terytorium Chorwacji oraz Słowenii. Obszar ten obejmuje ponad 180 tys. $\mathrm{km}^{2}$ powierzchni, zamieszkanej przez około 26 milionów ludzi. Społeczeństwo tego regionu mówi wieloma językami, należy do różnych kultur oraz przede wszystkim reprezentuje państwa o odmiennych doświadczeniach historycznych. Wśród obszarów działania Wspólnoty znalazły 
się między innymi turystyka, współpraca transgraniczna, ochrona środowiska, rozwój regionalny, bezpieczeństwo oraz oczywiście polityka narodowościowa (Alpen-Adria-Allianz, 2016).

Co ciekawe, impulsem dla powstania Wspólnoty była współpraca w sferze kultury, zapoczątkowana jeszcze w latach sześćdziesiątych. Po raz pierwszy nazwa Alpen - Adria pojawiła się w 1962 roku, przy okazji zorganizowania targów w Lublanie. Pojęcie to odnosiło się jednak jedynie do kilku przygranicznych włoskich i jugosłowiańskich wiosek. Szerszego znaczenia nabrało natomiast w roku 1967. Wtedy to bowiem sformalizowano współpracę kulturową między Karyntią, Fruli - Wenecją Julijską i Słowenią. Od tego momentu systematycznie organizowano wystawy artystów z tych trzech państw. Każdego roku ich gospodarzem zostawało inne państwo. Od 1968 roku odbywały się z kolei spotkania kulturalne pod nazwą „Tydzień kultury alpejsko-adriatyckiej”. Rok później do współpracy przyłączyła się Chorwacja (Valentin, 2006). Na początku lat siedemdziesiątych ubiegłego wieku wzajemne relacje uległy jednak ochłodzeniu. Karyntia, która do tej pory odgrywała rolę głównego inicjatora współpracy, borykała się wówczas z poważnymi problemami oraz ze wzrostem napięcia na tle etnicznym. Wraz z ustabilizowaniem sytuacji wewnętrznej w landzie powrócono do ścisłej współpracy ramach Wspólnoty Alpen-Adria.

Powyższe przykłady dowodzą, że Austria ma żywotny interes w utrzymaniu dobrych stosunków z południowym sąsiadem i to nie tylko z racji bliskości terytorialnej. Zepchnięta na peryferie integracji europejskiej podczas Zimnej Wojny, swoją uwagę bardzo często kierowała na państwa zza żelaznej kurtyny. Od dawna władze austriackie angażowały się w stabilizację sytuacji na Bałkanach. Odzwierciedleniem tego był chociażby fakt poparcia akcesji Słowenii do Unii Europejskiej. W związku z planowanym rozszerzeniem struktur unijnych władze austriackie dostrzegły szansę na utrwalenie stabilizacji politycznej w swoim bezpośrednim sąsiedztwie i stworzenia solidnych podstaw do rozszerzenia współpracy gospodarczej (Barcz, 2014). Ciekawy pozostaje fakt, że reakcje na proces rozszerzenia o inne państwa były wśród austriackiego społeczeństwa bardziej sceptyczne.

Relacje austriacko-słoweńskie nie należą do łatwych, chociażby z racji historycznych sporów wokół Karyntii. Fakt, że ich dobra kondycja leży w interesie obu stron, dostrzegany jest jednak również w Słowenii. Jej władze przyjęły w ostatnich latach kilka rozwiązań prawnych świadczących o zainteresowaniu problemem. Warto wspomnieć chociażby Rezolucję o położeniu autochtonicznych mniejszości słoweńskich w państwach ościennych i związanych z tym 
zadaniach rządu i innych organów Republiki Słowenii, czy Umowę między rządem Republiki Słowenii i rządem Republiki Austrii o współpracy w dziedzinie kultury, oświaty i nauki. W pierwszym dokumencie mowa jest o podjęciu przez rząd słoweński odpowiednich środków politycznych, kulturalnych oraz gospodarczych, w tym wzmocnienia współpracy na płaszczyźnie międzynarodowej, regionalnej i dwustronnej, których celem byłoby oczywiście wparcie mniejszości. Wśród przykładowych korzyści drugiego dokumentu znalazły się z kolei postanowienia dotyczące uznawania dyplomów i świadectw uzyskanych przez członków mniejszości w Słowenii, tworzenia sieci ułatwień mających na celu odbiór słoweńskich programów radiowych i telewizyjnych w Karyntii itp. (Novak, 2005/2006, s. 312-318).

\section{UWAGI KOŃCOWE}

Opisywane w artykule wydarzenia potwierdzają założenie, że polityka etniczna danego państwa w dużej mierze określana jest przez jego historię. Austria przez stulecia związana była z niemiecką dynastią Habsburgów. W drugiej połowie XIX wieku stanowiła wielonarodowy twór państwowy o skomplikowanej strukturze politycznej i administracyjnej. Po I wojnie światowej pozostawała pod wyraźnym wpływem nazistowskich Niemiec. W zasadzie dopiero od 1955 roku można mówić o całkowitej niezależności - także tej mentalnej.

Kilkusetletnie podporządkowanie miało wpływ na ludność słoweńskojęzyczną i wywoływało u niej niechęć w stosunku do władców frankijskich. Być może już w tym okresie należałoby doszukiwać się źródeł późniejszej wzajemnej niechęci mieszkańców Karyntii. Granica językowa na tym obszarze zaczęła się zarysowywać już w XV wieku.

Rozpad Austro-Węgier i powstanie nowych państw zrodziły pytanie o kształt i przebieg dotychczasowych granic. Peryferyjne usytuowanie Karyntii było jedną z przyczyn późniejszych sporów terytorialnych. Po przypieczętowaniu losów landu stosunki między Austrią a południowym sąsiadem zdominowane zostały następnie przez brak realizacji praw mniejszości słoweńskiej, w tym przede wszystkim postanowień artykułu 7 Traktatu Państwowego. Praktycznie od pierwszych lat jego obowiązywania władze jugosłowiańskie zgłaszały zastrzeżenia. Kwestia ta na długie lata zdominowała stosunki dyplomatyczne między państwami.

Władze w Lublanie interweniowały również w toczącym się później sporze o dwujęzyczne tablice topograficzne w Karyntii, który najostrzejsze formy przy- 
brał za rządów Jörga Haidera w roli gubernatora landu. Sprawą interesowały się słoweńskie media. Sytuacja uległa jednak poprawie wraz z podpisaniem w kwietniu 2011 roku w Klagenfurcie kompromisu w sprawie dwujęzycznych tablic z nazwami miejscowości. W pierwszych uroczystościach związanych z odsłonięciem tablic uczestniczyli premierzy Austrii oraz Słowenii. Coraz częściej pojawiają się głosy określające kompromis oraz jego szybką realizację jako historyczny moment i ogromny przełom we wzajemnych stosunkach.

Z drugiej jednak strony pojawiają się głosy krytykujące postawę władz słoweńskich. A. Novak pisał o pewnej wybiórczości i uznaniowości. Jego zdaniem rząd w Lublanie interweniował w przypadkach, w których mógł coś zyskać. W niektórych sytuacjach pozostawał natomiast bierny. Jako przykład podał okres po 2001 roku (a więc po orzeczeniu Federalnego Trybunału Konstytucyjnego dotyczącego nazw o charakterze topograficznym), kiedy odnotowywano liczne przypadki, gdy reprezentanci mniejszości ignorowani byli przez austriackich urzędników. Zaangażowanie władz słoweńskich w rozwiązanie problemu było w zasadzie zerowe (Novak, 2005/2006, s. 308-309). Ówczesną postawę rządu w Lublanie trzeba jednak rozpatrywać w szerszym kontekście. Należy pamiętać, że w omawianym okresie mieliśmy do czynienia $\mathrm{z}$ kulminacją procesu akcesyjnego Słowenii do Unii Europejskiej. Austria była wówczas jednym z państw, które w aktywny sposób popierały jej członkostwo. Obawa przed zaostrzeniem sytuacji w Karyntii była więc uzasadniona.

Nie ulega wątpliwości, że omawiane relacje nie należały do najłatwiejszych. Ich kondycja była i jest jednym z czynników wpływających na politykę etniczną Austrii, a tym samym na sytuację karynckich Słoweńców. Z drugiej strony historia pokazała, że relacje między państwami mają dla obu stron charakter strategiczny, zarówno w wymiarze politycznym, gospodarczym czy kulturalnym.

Sytuacja w Karyntii wydaje się współcześnie ustabilizowana. Wciąż dochodzi jednak do napięć między ludnością słoweńskojęzyczną a resztą mieszkańców landu. Całkowita normalizacja wzajemnych stosunków pozostaje raczej w sferze ideałów. Wraz ze wzrostem aktywności mniejszości słoweńskiej oraz ich samodzielności w różnych sferach życia, rośnie zazwyczaj niezadowolenie ze strony austriackiego społeczeństwa. Stanowi to idealne podłoże pod sytuacje konfliktowe. A to z kolei może pociągać za sobą w przyszłości kolejne „interwencje” władz słoweńskich. 
Bibliografia:

"Mörderische" SMS gegen Slowenen (2006). Pobrane z: http://www.derStandard.at.

2. Bericht zur Durchführung des Europäischen Rahmenübereinkommens zum Schutz nationaler Minderheiten in der Republik Österreich. NGO-Report, Austria, German 2007.

Alpen-Adria-Allianz (2015). Pobrane z: http://www.alps-adriatic-alliance.org/wp-content/uploads/2016/02/The-AAA-Factsheet-DEU.pdf.

Barcz, J., Austria w drugiej połowie lat 90. wobec „Rozszerzenia na Wschód” (Osterweiterung) Unii Europejskiej. W: A. Kiszteliński-Węgrzyńska, K.A. Kuczyńska (red.), Austria i relacje polsko-austriackie w XX i XXI wieku. Polityka - kultura-gospodarka (127-142). Łódź 2014.

Baumgartner, G. $6 x$ Österreich, Geschichte und aktuelle Situation der Volksgruppen, Klagenfurt 1995.

Bundesgesetz über den Österreichischen Rundfunk und Fernsehen/ORF-Gesetz, BGBl. I Nr. 97/2004.

Bundesgesetz über Vereine 2002, BGBl. I Nr 66/2002.

Bundesgesetz vom 7. 7. 1976 über die Rechtsstellung von Volksgruppen in Österreich (Volksgruppengesetz), BGBl. Nr. 396/1976.

Bundesgesetz, mit dem Bestimmungen über die Anbringung von zweisprachigen topographischen Bezeichnungen und Aufschriften in den Gebieten Kärntens mit slowenischer oder gemischter Bevölkerung (Ortstafelgesetz), BGBl. Nr 270/1972.

Chlebowczyk, J. (1983). O prawie do bytu małych i młodych narodów. Kwestia narodowa i procesy narodowotwórcze we wschodniej Europie środkowej w dobie kapitalizmu od schytku XVIII do początków XX wieku. Kraków.

Die Ortstafelfrage aus Expertensicht. Eine kritische Beleuchtung. Sonderband 01. Kärnten Dokumentation, Klagenfurt 2006.

Fischer, G. (2001). Das Slowenische in Kärnten. Eine Studie zur Sprachenpolitik, Wien 1980.

I am from Austria - Volksgruppen In Österreich, Österreichische Volksgruppenhandbücher, Band 11, Wien.

Karner, S. (2006). Die Bemühungen zur Lösung des Kärntner Minderheitenproblems 2005, W: Die Ortstafelfrage aus Expertensicht. Eine kritische Beleuchtung. Sonderband 01. Kärnten Dokumentation (81-110). Klagenfurt.

Kärntner Slowenen, Österreichische Volksgruppenhandbücher, Band 1, Wien 1993.

Minderheiten-Schulgesetz für Kärnten, BGBl. Nr. 101/1959.

Novak, A. (2005/2006). Der Rechtsschutz der slowenischen Minderheit in Österreich vor dem Hintergrund des neuen völkerrechtlichen Minderheitenschutzes. Wien.

Popławski, D. (1995). Austriacka polityka neutralności 1955-1995. Warszawa.

Slawisches Österreich - Geschichte und Gegenwart der Minderheiten. Die Slowenen in Kärnten (2006). Pobrane z: http://www-gewi.uni.graz.at/slaw/studium/ring_vo/ script/lk_slow-au.pdf.

Staatsvertrag von St. Germain, Staatsgesetzblatt Nr. 303/1920. 
Valentin, H. (2005). Der Sonderfall. Kärntner Zeitgeschichte 1918-2004. Klagenfurt-Ljubljana-Wien.

Volkszählung 2001. Hauptergebnisse I - Kärnten. Wien.

Volkszählung 2001. Hauptergebnisse I - Steiermark. Wien.

Vouk R., 60 Jahre Artikel 7 (2015). Pobrane z: http://nsks.at/deutsch/?p=1716.

Wereszycki, H. (1986). Pod berłem Habsburgów. Zagadnienia narodowościowe. Kraków. Wiederherstellung eines unabhängigen und demokratischen Österreich, BGBl. Nr. 152/1955. 